\title{
Perspectives for foreign language teachers' professional development in the German-Polish border region
}

\begin{abstract}
AвSTRACT. The aim of the paper is to identify key areas as well as to offer an overview of significant topics that should be addressed within training for foreign language teachers, enabling them to use the educational potential of the German-Polish border region in intercultural foreign languages teaching. In order to achieve this goal, in the first part of the paper the main concepts of pupiloriented education in a border region will be described (i.e. cross-border cooperation, learner-orientation, region-orientation, participation, sustainability, and competence for successful living and communicating in a border region), as they give insights into the essential fields of knowledge and skills that should be aimed at in terms of teacher-oriented activities during the process of professionalisation. On this basis, in the second part of the article, concrete recommendations on priority topics within the professional development of foreign language teachers will be made, according to the specific educational potential of the German-Polish border region.
\end{abstract}

KEYWORDS: German-Polish border region, professionalisation of teachers, foreign language teachers, trans-border educational activities, foreign language, neighbouring language.

\section{INTRODUCTORY REMARKS: RESEARCH AND METHODOLOGICAL CONTEXT}

In Europe, which is growing closer together, teachers of all subjects and at all levels of education need to respond to the contemporary educational challenges and opportunities presented by multiculturalism and multilingualism. Those challenges and opportunities are particularly tangible in the European border regions, and turning them into educational advantages is one of the features of teachers operating in intercultural border zones. A short review of the literature allows three aspects connected with border regions and educa- 
tion in border regions to be determined that seem to be of particular academic interest:

1. Border regions as privileged places, contexts and settings of foreign language and culture learning, as well as (inter)cultural laboratories enhancing the development of pupils' intercultural competence (see Halink, Schmitz-Schwamborn \& Raasch 2004; Breugnot \& Molz 2006; Hiller 2012; Badstübner-Kizik 2016; Lis 2016).

2. The possibilities and opportunities for cross-border cooperation between (local) educational institutions and other actors, e.g. schools, universities, (non-governmental) cultural institutions, boards of education (see Kaczmarek \& Edin-Kroll 2006; Arbeitsgemeinschaft Europäischer Grenzregionen 2008; Kliewer \& Čeřovská 2011).

3. The specifics of initial teacher training and professional development of teachers in border regions (see Busch, Lis \& Müller 2012; Busch, Lis \& Teichmüller 2016).

The first two of the above-mentioned elements, i.e. learner-oriented and institutional factors, have been the subject of a lively research-based exchange and closer analysis. The third one however, i.e. the teacher-oriented perspective, seems not to have been thoroughly and systematically enquired into and reflected upon so far. The possible reasons for the lack of research in this area (in the German-Polish border region), which is the focus of this paper, could be twofold in nature. Firstly, the political, institutional and financial conditions for a systematic use of educational potentials of the border region only fully emerged after Poland joined the European Union ${ }^{1}$. Thus, putting German and Polish cross-border teaching and learning opportunities into practice on a bigger scale, as well as researching them are relatively new phenomena. Secondly, the initial foreign language teachers' training is considerably unified in Poland and does not always take future teaching setting into account. There is no separate path of professional development foreseen for teachers of foreign languages (especially German as a foreign language) working in the German-Polish (or any other) border region.

However, the topic of cross-border educational cooperation that might seem as niche, is very promising, as professional preparation of foreign language teachers for exploiting educational opportunities deriving from the linguistic

${ }^{1}$ What is a significant aspect here is the intercultural educational cooperation in border regions of the countries that became members of the European Union after its biggest enlargement in 2004, e.g. extracurricular meetings for pupils in the German-Polish border region (see Busch, Lis \& Müller 2012), language projects for pupils in the border regions of Germany and Austria (see Kliewer \& Čeřovská 2011), or the BIG-Projects in the Hungarian-Austrian (BIG AT-HU), Czech-Austrian (BIG AT-CZ), or Slovak-Austrian (BIG SK-AT) border region (for detailed information see www. big-projects.eu, access: 12.08.2020). 
and cultural landscape of a border region helps to implement many elements of a modern foreign languages didactics, for example, the development of intercultural competence and the ability to successfully live and communicate in a border region [see the German term "Grenzkompetenz" (Raasch 2011; Raasch 2019)], or inclusion of extracurricular learning places that refer directly to a given language and culture. That is why teacher education, their attitudes, and the professional skills required to exploit the opportunities arising from teaching and learning in a border region should definitely move into the focus of interdisciplinary studies.

Against that backdrop, the aim of the paper is to discuss the specific possibilities of the professionalization of foreign language teachers in context of using the educational potential of the German-Polish border region. As far as teaching and learning neighbouring languages in the German-Polish border region is concerned, not only specific policies on different governmental levels on both sides of the border are introduced (see Raasch 2019: 470-471) but also numerous projects based on them are conducted (see Vogel \& Bień-Lietz 2008; Gellrich \& Vogel 2019; Gellrich 2019; Hryniewicz \& Lisek 2019). Yet, no results of longitudinal research on initial and / or continuous teachers' professional development in this regard are available. The present paper does not present outcomes of such research either. Methodologically the paper is based on observation, documentation and evaluation of the outcomes of two projects on the professional development of teachers in the border region carried out in the German-Polish euroregion Pro Europa Viadrina: "Terra Transoderana - deutsch-polnische Unterrichtsentwicklung" 2 and "Translimes - Schule in der Grenzregion" ${ }^{3}$, which were addressed to teachers of all school subjects, and therefore covered topics

2 "Terra Transoderana - deutsch-polnische Unterrichtsentwicklung", conducted from April 2010 till August 2012, was organized by the Förderverein Schloß Trebnitz BBZ e.V. in cooperation with Adam Mickiewicz University Poznań, the University of Hamburg and supported by the Euroregion Pro Europa Viadrina, the Youth Welfare Office of Brandenburg and the German-Polish Youth Office. The focus here was to develop intercultural teaching units on local aspects of the German-Polish border region which could be realized as interdisciplinary educational in-school and out-of-school projects, as an extracurricular addition to the daily curricular routine. Thus, it was possible to create a network of teachers from Germany and Poland who were interested in cooperating with each other on developing a local-oriented education in the German-Polish border region (for documentation see Busch, Lis \& Müller 2012).

3 “Translimes - Schule in der Grenzregion", conducted from November 2014 till December 2016, organized by the Schloß Trebnitz BBZ e.V. in cooperation with the Technical University of Kaiserslautern, the University of Hamburg and the University of Kiel and supported by the F.C. Flick Foundation, the Federal Agency for Civic Education and the European Union. The main goals of this programme were to develop formal and non-formal forms of education which would be local-coloured and border region-oriented, activating possible partnerships, and as a result to create a transnational school profile which would underline the unique character of the Translimes- 
of general interest for joint activities as part of lifelong learning of teachers from both countries. Based on the results of these projects, which are available in form of publications (see Busch, Lis \& Müller 2012; Busch, Lis \& Teichmüller 2016; Schloß Trebnitz BBZ e.V. 2016), a full documentation in the archives of the Schloß Trebnitz BBZ e.V., and as a film that summarizes the oral evaluation of the latter project $^{4}$, the paper identifies key areas, as well as offers an overview of significant topics that should be addressed within trainings for foreign language teachers that aim to enable them to use the educational potential of the German-Polish border region in the intercultural foreign languages didactics.

In order to achieve this goal, the following paper is divided into three parts. In the first one (Section 2), crucial notions of pupil-oriented education in the German-Polish border region will be characterised, as they lay ground for the main concepts, forms and methods of working with learners in the border region that should be discussed in frames of the teacher training. In the second part (Section 3), recommendations on professionalization of foreign language teachers in the German-Polish border region will be outlined. Finally, in the third part (Section 4), preliminary conclusions with regard to the potential of the German-Polish border region in the professionalization of foreign language teachers will be drawn.

\section{KEY CONCEPTS OF TRANS-BORDER PUPIL-ORIENTED EDUCATION AS FOUNDATION FOR TEACHERS' PROFESSIONALIZATION}

The starting point of the paper, as mentioned above, will be the description of the main features of the trans-border educational activities for pupils. At this point, it is important to underline that we do not perceive learner-oriented learning and culture projects as synonymous with teacher development, which is in line with the recent literature on teacher professional development (see England 2020). Nevertheless, a brief characteristic of the learner-oriented activities in the border region will allow identification of aspects which are important in the process of cross-border cooperation between teachers from different countries and which should be emphasized in their professional development.

Observing the trans-border educational activities for pupils conducted in recent years in the German-Polish border region (see educational projects described

-school, a specific type of school in the German-Polish border region, attractive both for German and Polish teachers, pupils and their parents (for documentation see Schloß Trebnitz BBZ e.V. 2016).

${ }^{4}$ For video report see http:/ / participation-transnational.eu/node/101 [access: 12.08.2020]. 
in e.g. Busch, Lis \& Müller 2012; Busch \& Teichmüller 2013; Busch, Lis \& Teichmüller 2016), their background concepts can be noticed in the following areas:

1. Cross-border cooperation: One of the main goals of the European Union is supporting cooperation between neighbouring countries, especially in border regions. Its aim is to develop trans-border structures which can create backdrops for sustainable economic and social growth. Of relevance here are the funding programmes of the European Regional Development Fund, e.g. Interreg (territorial cooperation between countries is supported within this programme on cross-border, transnational and interregional level). ${ }^{5}$ Education is one of the priorities of the European cohesion policy. ${ }^{6}$ That is why a network of trans-border euroregions, as well as the local governments in the German and Polish border zones are interested in developing intercultural relations between schools, their teachers and pupils. These contacts might be of great importance for border regions, which, on the one hand, are often described as infrastructurally weak regions with high emigration rates and low economic value, ${ }^{7}$ and, on the other hand, are seen as "engines of European integration" (Busch \& Teichmüller 2016: 48), "laboratories for multilingualism" (Kowalonek-Janczarek 2011: 98), or "laboratories for regional-oriented educational concepts" (Gellrich 2019: 103) because of their potential for sustainable work across and beyond the boundaries. In the German-Polish border region there are numerous joint educational activities carried out by local German and Polish schools of different types which aim at getting to know each other through cooperative work in projects on topics of their mutual interest. These are of great value not only for pupils, who get the opportunity to learn in intercultural and multilingual settings, but also for teachers, who can exchange their teaching experience with their colleagues from abroad and gain insights into the educational concepts, structures and tools in the neighbouring countries.

2. Learner-orientation: Most of the trans-border educational activities are projects developed according to pupils' needs and interests. This is how projects as an open form of learning are organized - the pupils take part in the planning and preparing the educational activity, so that their

${ }^{5}$ For detailed information see https:/ / ec.europa.eu/regional_policy/en/policy/cooperation/ european-territorial/ [access: 11.04.2020].

${ }^{6}$ See priorities within the programme Interreg V for the years 2014-2020: https:/ /ec.europa. eu/regional_policy/ en/policy/how/priorities [access: 11.04.2020].

${ }^{7}$ For detailed information see e.g. the report on the situation in the neighbouring Brandenburg (Germany) and Lubuskie Region (Poland): https:/ / www.euroregion-viadrina.de/wp-content/ uploads/Programm-DE-final-300915_download_160226.pdf, pp. 5-12 [access: 11.04.2020]. 
suggestions and priorities are taken into consideration. The pupil is the main actor in all phases of the educational project (planning, conducting, evaluating), whereas the teacher's role is more supportive in the process, but leading in its methodology 8 .

3. Region-orientation: Many educational activities deal with local issues which may concern the pupils. Topics or problems which correspond with their daily life and cover both in-school and out-of-school issues show the comprehensive character of learning. There is a possibility of developing educational activities which go beyond the curriculum and are completed through extracurricular content set in the local area. In this way, the learning process takes place not only in the classroom, but also outside the school, e.g. in public (buildings, parks, squares etc.) or domestic spaces, with the use of content gained not only from course books and other teaching materials, but also collected on the spot and in settings different from the classroom or school grounds (see Kaiser 2011: 23-24). By doing this, the pupils discover their local area anew and - what is more - identify themselves with the tasks given as part of the educational activity. ${ }^{9}$

4. Participation: The pupils are motivated to take part in educational activity which is not an abstract act of gaining knowledge, but rather a particular action with a concrete purpose. Thanks to the practice-oriented aspects of education conducted with content referring to their local contexts, the pupils have the feeling that they are dealing with real matters which concern them directly and are important for their future life (see Chott 1990: 14). It moves them to critical observation of their local community and the whole border region, as well as motivates them to take actions in the process of its modification, e.g. to comment on contemporary challenges, to reflect on current problems, to suggest proper improvements (see Bastian \& Gudjons 1990: 31-32). They are invited to participate in creating and developing trans-border social, political and cultural structures, and therefore become actors in the process of the democratisation of their local areas. The German-Polish border region needs such engaged actors and sustainable structures to function as an intercultural and multilingual place in the network of the European regions.

${ }^{8}$ The methodological recommendations on the project method by William H. Kilpatrick from the beginning of the $20^{\text {th }}$ century (see Kilpatrick 1918) are still topical in the context of the discussion about educational projects in recent years.

${ }^{9}$ For more concrete educational projects on learning a foreign language in the German-Polish border region see e.g. Antoniewicz-Gawron and Janachowska-Budych 2012 (English as a foreign language) or Lis 2018 (German as a foreign language). 
5. Sustainability: The aim of most trans-border educational activities for schools in the German-Polish border region is to impart knowledge and practical skills to the pupils, and to show them the ways of applying these in local contexts. Some of the results, such as the simulation of a German-Polish intercultural restaurant (see Klapper \& Strebel 2012), or a real village café run by the pupils from local schools in Germany and Poland as part of their own small company (see Teichmüller 2013; Teichmüller 2016), can be seen as particular steps in developing and implementing new ideas within education in the field of professional skills and on a local labour market. Other ones, such as organizing German-Polish youth summits (Deutsch-Polnische Jugendagora, see Busch 2011; Busch 2013), or of the trans-border youth parliament (Deutsch-Polnischer Oderjugendrat, see Lucht 2013; Lucht 2016) prepare the pupils for participation in political discourse and the processes of decision-making in their local areas. Through the educational activities, sustainable structures and networks are established which modify the status of the German-Polish border region - from a divided periphery to a meeting place of different policies, cultures, languages and points of view from both sides of the border.

6. Competence for successful living and communicating in a border region: In frames of trans-border cooperation of any kind a border region is perceived as a network of players who are creating the mutual space for communication between the participating societies. The communication itself is based on initialized, developed and established contacts, what constantly refreshes the connections between the border societies, as well as redefines the melting points of their communication, and recreates the border region as its playground. That is why it is important to support a specific kind of intercultural competence developed especially for border regions, which would maintain the process of growing together, and strengthen the process of internationalization of life in a border region, knowing its weak and strong features. Raasch's concept of "Grenzkompetenz" includes a set of social skills (among them the language competence) which enable one to manage the contacts and the communication in a way which is suitable for successful daily life in the border region (see Raasch 2011: 12; Raasch 2019: 469).

Planning, conducting and evaluating trans-border educational activities for pupils is a source of much profit for teachers as well. New cross-border professional contacts made by teachers from Germany and Poland create backgrounds for the intercultural exchange of teaching experiences. Through adding educational settings other than in school, and implementing teaching concepts in cooperation with public institutional and non-institutional partners (e.g. other 
educational establishments, museums, theatres, cinemas, non-governmental organizations, local companies) the form of learning is modified. Possible transborder educational contents are accessible in two forms (see Badstübner-Kizik 2016: 117-118; Lis 2018: 246):

1) as direct regional resources such as (well-known or unknown) inhabitants of the region, specific objects and spaces or events provided in the border region;

2) as mediated resources such as collections, photos, postcards, stamps, coins, objects of everyday use, historical and contemporary documents and other publications from and about the border region, or media reports and coverages from and about the border region (press, radio, television, cinema).

However, many teachers are only faced with trans-border education once they spontaneously start the preparation for a German-Polish educational project, and that is why they often regard it as a big challenge. Nevertheless, would it be possible to prepare them for it, and if so, how to do it?

\section{RECOMMENDATIONS ON PROFESSIONALIZATION OF FOREIGN LANGUAGE TEACHERS IN THE GERMAN-POLISH BORDER REGION}

The reflection upon a development of a systematic professionalization programme for foreign language teachers in the German-Polish border region will proceed in two steps. The needs and wishes of the teachers regarding their professionalization will be identified and classified, and consequently specific recommendations on specific topics will be made.

The reports of teachers from both sides of the border who are involved in German-Polish trans-border educational activities as coordinators demonstrate their will to participate in a long-term preparation process of cooperation with teachers and pupils from the other country. ${ }^{10}$ Their need for professionalization within this task concerns three main areas.

Firstly, they see the necessity of getting to know each other both on a personal and institutional level. Knowing the aims of each national educational policy and the individual educational concepts and goals of each school could allow them to create intentional cooperation between schools from Germany and Poland, and develop joint educational projects adapted to the specific needs and interests of their pupils. Equally important is the knowledge of different work regimes and

\footnotetext{
${ }^{10}$ Relevant here are the oral reflections of German and Polish teachers, who took part in the project on the professional development of teachers "Translimes - Schule in der Grenzregion" in the years 2014-2016, see http:/ / participation-transnational.eu/node/101 [access: 12.08.2020].
} 
schedules which might help the cooperation run smoothly. An example of this is the fact that many teachers from Poland are willing to conduct German-Polish projects for pupils at weekends, as in Poland there are no "project weeks" so well-known to German teachers. If a Polish teacher is absent from work because of a project, she or he must make up for the lessons missed, which means extra effort and time. German teachers are excused from work because of projects, and so they see no reason to give up their free time at weekends.

Secondly, methodological support while planning, conducting and evaluating trans-border educational activities would be significant in the form of contact with external experts, e.g. co-workers from the public administration, actors of non-formal educational establishments, activists in non-governmental organisations, businessmen, academics or university teachers from both sides of the border to gain access to modern forms of learning, and to arrange alternative educational settings. An exchange with external experts could open the school to the possibilities of sustainable teaching and learning processes set in local contexts with benefits for the local community of the German-Polish border region.

Finally, teachers in the Polish-German border region need support in raising funds for trans-border educational activities for pupils. More information about alternative sources of outside funding for intercultural projects for schools (e.g. the German-Polish Youth Office, the Federal Agency for Civic Education) and help in completing the necessary forms and documents are regarded as essential.

Going one step further and trying to satisfy the needs and wishes verbalized by teachers who are involved in cross-border educational projects in the German-Polish border region, specific recommendations can be suggested. There are examples of successful projects devoted to trans-border education in European border regions, based on successful work in the field of cross-border teachers' training ${ }^{11}$. Nevertheless, the following recommendations are made to underline fields which are significant for professionalization programmes for foreign language teachers in the German-Polish border region, aimed at successful transborder cooperation in the area of teaching a foreign language ${ }^{12}$.

${ }^{11}$ Significant aspects here are i.e. transnational school forms in the German-Danish (see Christiansen 2016b), German-Polish (see Metz 2016), German-Luxembourgish (see Staudt 2016), or German-French (see Bächle 2016) border region.

${ }^{12}$ The recommendations discussed in the following paper focus on the German-Polish border region, its intercultural and multilingual potential, which can be used in a process of developing of a local-oriented education on the border. However, some of them refer also to other European border regions, where interesting ideas for joint activities in the field of school education have been already described in the literature, i.e.: in the German-Danish border region: a description of a project of a German-Danish class between cooperating schools on secondary level (see Christiansen 2016a), or a set of educational materials for learning German or Danish as a neighbouring language (see Kahlert-Silzle, Stoubye Blavnsfeldt \& Muth-Ries <n.y.>; Baunsgaard Koll \& Hallsteinsdóttir <n.y.>), 
Like every border region, the German-Polish border region is also an interesting intercultural and multilingual place, offering a wide range of educational possibilities, which can be utilised for the purpose of learning a foreign language. It is especially relevant for German and Polish as foreign languages, for which there are already concepts of teaching them as neighbouring languages of the region (see e.g. Vogel \& Bień-Lietz 2008; Becker \& Fleischer-Wetzel 2014; Gellrich \& Vogel 2019; Hryniewicz \& Lisek 2019). But above this, there are several forms of education which can be used as additional activities supporting the institutionalised language teaching process, e.g.:

1) intercultural meetings for pupils on different topics, where language teaching is an accompanying activity to the main activities on other subjects, e.g. sports, art, theatre, but also mathematics, physics, chemistry etc. (either in the form of out-of-school meeting projects for pupils, or as in-school meetings for pupils within the framework of the "Latarnia" project - conducted since 1992 between the Karl-Liebknecht-Gymnasium in Frankfurt (Oder) and the Szkoła Podstawowa nr 2 im. Tadeusza Kościuszki in Słubice / the former Gimnazjum nr 2 im. Marka Kotańskiego in Słubice ${ }^{13}$ );

2) bilingual tandem-programmes for both learners of German and Polish as foreign languages;

3) trans-border projects on learning foreign languages other than German or Polish (e.g. English, Spanish, French or Russian), where the taught language is not the mother tongue for either of the groups of learners.

Each of these forms of education needs to be prepared according to the current methodological recommendations of experts who help to choose the main topics, find suitable content, materials, methods and tools, settled in appropriate

or for getting to know the geographical, social, cultural and political specific of the German-Danish border region (see Hallsteinsdóttir, Baunsgaard Koll, Le Müller \& Kilian 2015; Raahauge Muntenjon \& Dideriksen 2018; Kehlet Kurz \& Lykke Varming 2019; Jensen 2019). For more materials see www. kulturakademi.de [access: 12.08.2020]; in the German-French border region: the dynamics between neighbouring languages French and German discussed from the perspective of historical linguistics, conflict linguistics, contact linguistics and ecolinguistics (see Schneider-Mizony 2014), or teachers' attitude towards neighbouring country and neighbouring language in the German-French border region (see Putsche \& Faucompré 2017); in the Hungarian-Austrian border region: a handbook for teaching German and Hungarian as neighbouring languages on preschool and primary level (see Fischer-Badr 2019); in the German-Polish-Czech region: publications of the Saxon State Office for Early Neighbour Language Education for learning German, Polish and Czech, for more materials see www.nachbarsprachen-sachsen.eu [access 12.08.2020].

${ }^{13}$ The reports on the project can be found on the websites of the participating schools, see e.g. https:/ / sp2slubice.edupage.org/a/ projekt-latarnia [access: 11.04.2020] or http:/ /liebknechtgymnasium.de/en/ schulprofil/latarnia-projekt.html [access: 11.04.2020]. 
out-of-school settings, and finally support the teachers in the process of creating teaching materials.

The next aspect of a teacher's work in the border region is its intercultural and multilingual character. That is why detailed reflection on the intercultural skills of teachers and their intercultural competence should be a part of the professionalization of teachers of foreign languages in the German-Polish border region. Aspects, such as concepts of culture, cultural dimensions and standards, productive work with stereotypes, aspects of verbal and non-verbal communication, conflict management in intercultural situations etc., should be discussed widely in the German-Polish context, in consideration of the specific meaning of the border, offering chances of daily interactions between both cultures and languages. Experts from the fields of intercultural communication, psychology, sociology or history would be appropriate for conducting complex intercultural training with the main goal of developing and considering one's own intercultural competence, and learning how to use it for trans-border cooperation between schools.

As a significant element, and the "voice" of culture, language constantly undergoes changes which reflect the modifications within the culture itself. That is why it is important to keep up with these changes. The recommended professionalization of foreign language teachers should include special practical units to improve language skills. However, it would be important to plan these units considering the individual needs of the teachers, resulting from their current challenges at work. Out of many examples of teacher-oriented language courses, especially appealing would be classes on e.g. youth language, the language of social media (analysis of comments on Facebook, photo descriptions on Instagram etc.), language of different lines of business and service (e.g. business German / Polish / English for the border region, the language of different services - geriatric care, accommodation industry, gastronomy, car service etc.) - also to fulfil the needs of the pupils, preparing themselves for activity in the local labour market.

Last, but not least, it is important to know where to apply for the financial resources which make trans-border cooperation between schools possible. A module on available sources of funds should be a compulsory component in the professionalization of foreign language teachers in the German-Polish border region. It is crucial, as although there are numerous German, Polish and European bodies which are open to financing educational activities for pupils from the border region, they are often not known to many teachers. Highlighting the wide range of possibilities of financial support and advice, detailing how to prepare and submit the required forms and documents (applying for funds, raising funds and writing final reports) might even convince some of the teachers - especially those not experienced in the paperwork covering the financial side of education - to try their hands at coordinating a trans-border activity. 


\section{CONCLUSIONS}

In planning, conducting and evaluating joint (German-Polish) educational activities - thanks to such challenges as preparing a binational project, school exchange, study trip or lessons - teachers have to compare, or sometimes even update their subject knowledge, and adapt their working methods to the needs of their partners from the other country, as well as to the needs of a very specific, binational group of learners. Therefore, such joint trans-border educational initiatives give teachers the possibility to improve their teaching skills and develop their competence, such as being active, self-directed, creative, responsible etc. - which is of course possible in monocultural contexts - but also being open to a dialogue with different cultures, including different teaching and learning styles and practices.

The German-Polish border region could become a mine of ideas for transborder educational - including out-of-school - activities. Teaching in a border region especially invites incorporating local, binational topics, places, events etc., also in the course of teaching foreign languages. However, discovering those regional trans-border resources, adapting them for the educational needs of teaching and learning a foreign language, and their successful implementation into educational practice is another challenging, but also developmental task for teachers. Exploiting the educational chances offered by living in a border region, building trans-border teacher and school networks in order to specifically enhance pupils' development, as well as teachers' professional and intercultural competence - this all requires from the teachers a constant openness to the culture of the neighbouring country, and a readiness to implement transnational education into their everyday teaching practices, so that the idea of a modern, innovative and tolerant Europe of regions can become a fact.

Using the resources available in the German-Polish border region in the lifelong learning and professionalization of foreign language teachers is a topic that needs to be further researched and systematised. Nevertheless, the European border regions bear a lot of educational potential that is seen and recognised by teachers themselves.

\section{REFERENCES}

Antoniewicz-Gawron, E. / Janachowska-Budych, M. (2012). Love, friendship and music on the border. Przystanek Woodstock as a meeting place of Polish and German youth. In: M. Busch / T. Lis / D. Müller (eds.), Lernen jenseits der Oder. Lehrerhandreichung für deutsch-polnische Unterrichtsprojekte. Konzepte und Materialien für regionalspezifische Unterrichtseinheiten (pp. 77-90). Poznań: Garmond Oficyna Wydawnicza. 
Arbeitsgemeinschaft Europäischer Grenzregionen (2008). Wachsende Regionen, wachsendes Europa. Konsultation der Öffentlichkeit zur Zukunft der europäischen Kohäsionspolitik. Stellungnahme der Arbeitsgemeinschaft Europäischer Grenzregionen (AGEG). https://www.aebr.eu/files/publications/ Arbeitsgemeinschaft_Europ_ischer_GrenzregionenDE.pdf [access: 11.04.2020].

Bächle, H. (2016). Das war die Zeit, in der wir es geschafft haben, die Schule so zu gestalten, dass sie den Namen auch verdient [an interview]. In: M. Busch / T. Lis / N. Teichmüller (eds.), Bildung grenzenlos vernetzen. Transnationale Bildungs- und Partizipationslandschaften in europäischen Grenzregionen (pp. 344-347). Trebnitz: Schloß Trebnitz BBZ e.V.

Badstübner-Kizik, C. (2016). Gemeinsam lernen im Grenzbereich? Zu den Grundlagen einer regionalen Kontaktdidaktik. In: M. Busch / T. Lis / N. Teichmüller (eds.), Bildung grenzenlos vernetzen. Transnationale Bildungs- und Partizipationslandschaften in europäischen Grenzregionen (pp. 110-126). Trebnitz: Schloß Trebnitz BBZ e.V.

Bastian, J. / Gudjons, H. (1990). Projektunterricht: Geschichte und Konzepte als Perspektiven innerer Schulreform. In: J. Bastian / H. Gudjons (eds.), Das Projektbuch II: Über die Projektwoche hinaus. Projektlernen im Fachunterricht (pp. 17-42). Hamburg: Bergmann + Helbig Verlag.

Baunsgaard Koll, P. / Hallsteinsdóttir, E. (n.y.). Mit Deutsch kommt man weiter. Deutsch-dänische Wirtschaftskommunikation/Aufgabenheft. Padborg: Region Sønderjylland-Schleswig / Regionskontor \& Infocenter.

Becker, K. / Fleischer-Wetzel, A. (2014). Die Nachbarsprache erlernen in Frankfurt (O.) - Słubice. Auf dem Weg zu einer gemeinsamen Region. In: Schloß Trebnitz BBZ e.V. (ed.), Lebendige Nachbarschaft. Praktizierte gesellschaftliche Beteiligung auf deutsch-polnisch. Projektdokumentation: "Deutsch-polnisches Netzwerk für transnationale Partizipation" (pp. 41-45). Trebnitz: Schloß Trebnitz BBZ e.V.

Breugnot, J. / Molz, M. (eds.) (2006). Europa konkret! Grenzräume als Chance für Bildungsinnovationen? Landau: Knecht Verlag.

Busch, M. (2011). Grenzenlos mitmischen. Deutsch-polnische Jugendagora. In: Schloß Trebnitz BBZ e.V. [D. Müller / Ch. Berendt / I. Sallmann] (eds.), Schloß Trebnitz. Jahresbericht 2010 (pp. 14-17). Trebnitz: Schloß Trebnitz BBZ e.V.

Busch, M. (2013). Die deutsch-polnische Jugendagora - Jugendliche als Experten in transnationalen Gestaltungsprozessen. In: M. Busch / N. Teichmüller (eds.), Europa leben und gestalten. Transnationale Bildungs- und Beteiligungsformen in der deutsch-polnischen Grenzregion (pp.34-45). Trebnitz: Schloß Trebnitz BBZ e.V.

Busch, M. / Lis, T. / Müller, D. (eds.) (2012). Lernen jenseits der Oder. Lehrerhandreichung für deutsch-polnische Unterrichtsprojekte. Konzepte und Materialien für regionalspezifische Unterrichtseinheiten. Poznań: Garmond Oficyna Wydawnicza.

Busch, M. / Lis, T. / Teichmüller, N. (eds.) (2016). Bildung grenzenlos vernetzen. Transnationale Bildungs- und Partizipationslandschaften in europäischen Grenzregionen. Trebnitz: Schloß Trebnitz BBZ e.V.

Busch, M. / Teichmüller, N. (2016). Transnationale Schulentwicklung in europäischen Grenzregionen. In: M. Busch / T. Lis / N. Teichmüller (eds.), Bildung grenzenlos vernetzen. Transnationale Bildungs- und Partizipationslandschaften in europäischen Grenzregionen (pp. 48-53). Trebnitz: Schloß Trebnitz BBZ e.V.

Busch, M. / Teichmüller, N. (eds.) (2013). Europa leben und gestalten. Transnationale Bildungs- und Beteiligungsformen in der deutsch-polnischen Grenzregion. Trebnitz: Schloß Trebnitz BBZ e.V.

Chott, P. (1990). Projektorientierter Unterricht. Eine Einführung. Weiden: Schuch-Verlag.

Christiansen, M. (2016a). Die deutsch-dänische Europaklasse - Geschichte eines Mischerfolges. In: M. Busch / T. Lis / N. Teichmüller (eds.), Bildung grenzenlos vernetzen. Transnationale 
Bildungs- und Partizipationslandschaften in europäischen Grenzregionen (S. 300-326). Trebnitz: Schloß Trebnitz BBZ e.V.

Christiansen, M. (2016b). Ein Bewusstsein dafür schaffen, dass gerade die Grenzregionen mit ihren kulturellen Überschneidungen etwas typisch Europäisches sind [an interview]. In: M. Busch / T. Lis / N. Teichmüller (eds.), Bildung grenzenlos vernetzen. Transnationale Bildungs- und Partizipationslandschaften in europäischen Grenzregionen (S. 363-366). Trebnitz: Schloß Trebnitz BBZ e.V.

England, L. (2020). TESOL career path development: Creating professional success. New York / London: Routledge.

Fischer-Badr, J. (2019). Fremdspracherwerb in lebensechten Situationen an der Nahtstelle Kindergarten - Schule. Theoretische und didaktisch-methodische Aspekte. Leitfaden für die Schuleingangsphase. St. Pölten: Amt der NÖ Landesregierung / Abteilung Kindergärten.

Gellrich, R. (2019). Auf dem Weg zur "Nachbarsprache von Anfang an" im deutsch-polnischen Grenzregion. Polski w Niemczech / Numer specjalny 2019/2020: Emil Krebs i wielojęzyczność w Europie, 103-112.

Gellrich, R. / Vogel, T. (eds.) (2019). Nachbarsprachenbildung in den deutsch-polnischen und deutschtschechischen Grenzregionen. Frankfurt (O.): Sprachenzentrum Europa-Universität Viadrina Frankfurt (Oder).

Halink, R. / Schmitz-Schwamborn, G. / Raasch, A. (eds.) (2004). Von der modernen Fremdsprachendidaktik zu ihren spezifischen Ausprägungen in Grenzregionen - Nachbarsprachenlernen. Borken: Kreisschulamt.

Hallsteinsdóttir, E. / Baunsgaard Koll, P. / Le Müller, K. / Kilian, J. (2015). Typisch deutsch - typisch dänisch? SMiK-Unterrichtsmaterialien zur Bewusstmachung von nationalen Stereotypen. Odense: SMiK-Projekt.

Hiller, G.G. (2012). Interkulturelle Kompetenz für deutsche und polnische Jugendliche in der Grenzregion. In: M. Busch / T. Lis / D. Müller (eds.), Lernen jenseits der Oder. Lehrerhandreichung für deutsch-polnische Unterrichtsprojekte. Konzepte und Materialien für regionalspezifische Unterrichtseinheiten (pp. 43-53). Poznań: Garmond Oficyna Wydawnicza.

Hryniewicz, J. / Lisek, G. (2019). Nauka języka sąsiada: Od kształcenia przedszkolnego do zawodowego. Rozwiązania dydaktyczne i organizacyjne na Pomorzu Przednim. In: K. ZiołoPużuk (ed.), Panorama glottodydaktyki polonistycznej. Wyzwania, pytania, kierunki (pp. 149-162). Warszawa: Wydawnictwo UKSW.

Jensen, A. (ed.) / Jacobsen, M.L. / Schou, N. / Vestergaard, G. (2019). Im Grenzgebiet-gemeinsames Leben im Grenzgebiet. Padborg: Region Sønderjylland-Schleswig / Regionskontor \& Infocenter.

Kaczmarek, T. / Edin-Kroll, M. (eds.) (2006). Polen und Deutschland. Von Nachbarschaft zu Partnerschaft. Interdisziplinäre Beiträge von der 1. Polnisch-Deutschen Sommer-Akademie in Ciążeń 9.07.-15.07.2006. Poznań: Bogucki Wydawnictwo Naukowe.

Kahlert-Silzle, S. / Stoubye Blavnsfeldt, J. / Muth-Ries, S. (n.y.). Vi lærer tysk / Wir lernen Dänisch. Padborg: Region Sønderjylland-Schleswig / KursKultur.

Kaiser, A. (2011). Praxisbuch Grundschulprojekte. Baltmannsweiler: Schneider Verlag Hohengehren. Kehlet Kurz, T. / Lykke Varming, C. (2019). Kaulquappe \& Bænkebider: grænseløse naturoplevelser / grenzenlose Naturerlebnisse. Padborg: Region Sønderjylland-Schleswig / KursKultur.

Kilpatrick, W.H. (1918). The project method. Teachers College Record, 19 (4), 319-335.

Klapper, J. / Strebel, H. (2012). Der Fall "Restaurant Oderterrassen" - Lebens- und Arbeitsperspektiven in der Grenzregion. In: M. Busch / T. Lis / D. Müller (eds.), Lernen jenseits der Oder. Lehrerhandreichung für deutsch-polnische Unterrichtsprojekte. Konzepte und Materialien für regionalspezifische Unterrichtseinheiten (pp. 135-149). Poznań: Garmond Oficyna Wydawnicza. 
Kliewer, A. / Čeřovská, M. (eds.) (2011). Wider den Einheitsunterricht. Deutschlernen an der Grenze. Liberec: Technische Universität Liberec.

Kowalonek-Janczarek, M. (2011). Überlegungen zum Fremdsprachenlernen in mehrsprachigen und multikulturellen Kontexten. In: A. Kliewer / M. Čeřovská (eds.), Wider den Einheitsunterricht. Deutschlernen an der Grenze (pp. 94-105). Liberec: Technische Universität Liberec.

Lis, T. (2016). Euroregion Pro Europa Viadrina als interkulturelles Feld der grenzüberschreitenden Zusammenarbeit zwischen Deutschen und Polen. In: M. Busch / T. Lis / N. Teichmüller (eds.), Bildung grenzenlos vernetzen. Transnationale Bildungs- und Partizipationslandschaften in europäischen Grenzregionen (pp. 54-71). Trebnitz: Schloß Trebnitz BBZ e.V.

Lis, T. (2018). Nauczanie języka niemieckiego jako obcego w polsko-niemieckim regionie przygranicznym - realizacja treści regionalnych za pomocą elementów metody projektów. In: B. Hufeisen / D. Knorr / P. Rosenberg / Ch. Schroeder / A. Sopata / T. Wicherkiewicz (eds.), Sprachbildung und Sprachkontakt im deutsch-polnischen Kontext (pp. 241-258). Berlin: Peter Lang.

Lucht, Ch. (2013). Deutsch-polnischer "Oderland-Jugendrat" - Einmischen ausdrücklich erwünscht. In: M. Busch / N. Teichmüller (eds.), Europa leben und gestalten. Transnationale Bildungs- und Beteiligungsformen in der deutsch-polnischen Grenzregion (pp. 46-66). Trebnitz: Schloß Trebnitz BBZ e.V.

Lucht, Ch. (2016). Fünf Jahre deutsch-polnischer Oderjugendrat - Beteiligung grenzüberschreitend erwünscht. In: M. Busch / T. Lis / N. Teichmüller (eds.), Bildung grenzenlos vernetzen. Transnationale Bildungs- und Partizipationslandschaften in europäischen Grenzregionen (pp. 202-210). Trebnitz: Schloß Trebnitz BBZ e.V.

Metz, R. (2016). So ein Gebilde ist sehr sensibel [an interview]. In: M. Busch / T. Lis / N. Teichmüller (eds.), Bildung grenzenlos vernetzen. Transnationale Bildungs- und Partizipationslandschaften in europäischen Grenzregionen (pp. 349-353). Trebnitz: Schloß Trebnitz BBZ e.V.

Putsche, J. / Faucompré, Ch. (2017). Lehrkontext Grenzregion: Affekt und Kognition von FremdsprachenlehrerInnen der Nachbarsprache. Zeitschrift für Interkulturellen Fremdsprachenunterricht, $22(2), 143-154$.

Raahauge Muntenjon, A. / Dideriksen, A.-S. (2018). Zwei Länder - ein Arbeitsmarkt / To lande - ej arbejdsmarked. Padborg: Region Sønderjylland-Schleswig / KursKultur.

Raasch, A. (2011). Im Fokus: die Sprachen. Grenzregionen rücken in das Zentrum des Interesses. In: A. Kliewer / M. Čeřovská (eds.), Wider den Einheitsunterricht. Deutschlernen an der Grenze (pp. 5-14). Liberec: Technische Universität Liberec.

Raasch, A. (2019). Didaktik der Grenzregionen. In: Ch. Fäcke / F.-J. Meißner (eds.), Handbuch Mehrsprachigkeits- und Mehrkulturalitätsdidaktik (pp. 469-472). Tübingen: Narr Francke Attempto.

Schloß Trebnitz BBZ e.V. (2016). Projektdokumentation "Translimes - Schule in der Grenzregion". Trebnitz: Schloß Trebnitz BBZ e.V.

Schneider-Mizony, O. (2014). Nachbarsprachen: Historio-, Konflikt-, Kontakt- oder Ökolinguistik? Zeitschrift des Verbandes Polnischer Germanisten, 3 (1), 75-88.

Staudt, V. (2016). Schule ist mehr als Unterricht [an interview]. In: M. Busch / T. Lis / N. Teichmüller (eds.), Bildung grenzenlos vernetzen. Transnationale Bildungs- und Partizipationslandschaften in europäischen Grenzregionen (pp. 357-360). Trebnitz: Schloß Trebnitz BBZ e.V.

Teichmüller, N. (2013). Deutsch-polnische Schülerfirma “Kaffee zum Glück" - inklusive und interkulturelle Bildung in einer transnationalen Arbeitswelt. In: M. Busch / N. Teichmüller (eds.), Europa leben und gestalten. Transnationale Bildungs- und Beteiligungsformen in der deutsch-polnischen Grenzregion (pp. 67-78). Trebnitz: Schloß Trebnitz BBZ e.V.

Teichmüller, N. (2016). Deutsch-polnische Schülerfirma "Kaffee zum Glück" - Kontinuität und Veränderung. In: M. Busch / T. Lis / N. Teichmüller (eds.), Bildung grenzenlos vernetzen. Trans- 
nationale Bildungs- und Partizipationslandschaften in europäischen Grenzregionen (pp. 232-243). Trebnitz: Schloß Trebnitz BBZ e.V.

Vogel, T. / Bień-Lietz, M. (eds.) (2008). Frühstart in die Nachbarsprache. Handbuch für den Spracherwerb in der deutsch-polnischen Grenzregion. Frankfurt (O.): Europa-Universität Viadrina Frankfurt (Oder).

Received: 15.04.2020; revised: 12.10 .2020

TOMASZ LIS

Christian-Albrechts-Universität zu Kiel

t.lis@slav.uni-kiel.de

ORCID: 0000-0002-4837-9596

MARTA JANACHOWSKA-BUDYCH

Uniwersytet im. Adama Mickiewicza w Poznaniu

maja@amu.edu.pl

ORCID: 0000-0002-9088-5732 